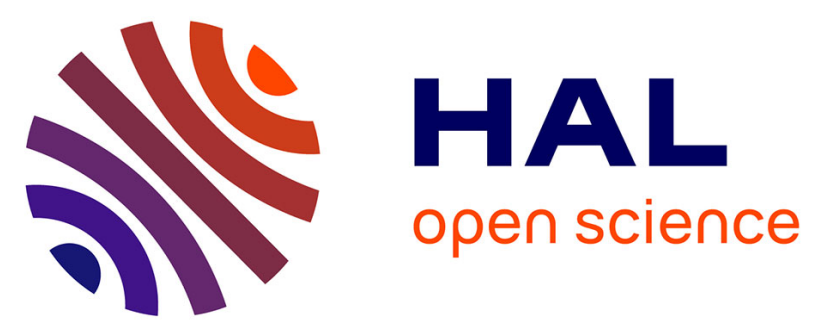

\title{
Assessment of seasonal variability of biomarkers in three-spined stickleback (Gasterosteurs aculatus L) from a low contaminated stream: implication for environmental biomonitoring
}

Wilfried Sanchez, Benjamin Piccini, Jean-Maxence Ditche, Jean-Marc Porcher

\section{- To cite this version:}

Wilfried Sanchez, Benjamin Piccini, Jean-Maxence Ditche, Jean-Marc Porcher. Assessment of seasonal variability of biomarkers in three-spined stickleback (Gasterosteurs aculatus L) from a low contaminated stream: implication for environmental biomonitoring. Environment International, 2008, 34 (6), pp.791-798. 10.1016/j.envint.2008.01.005 . ineris-00961926

HAL Id: ineris-00961926

https://hal-ineris.archives-ouvertes.fr/ineris-00961926

Submitted on 20 Mar 2014

HAL is a multi-disciplinary open access archive for the deposit and dissemination of scientific research documents, whether they are published or not. The documents may come from teaching and research institutions in France or abroad, or from public or private research centers.
L'archive ouverte pluridisciplinaire HAL, est destinée au dépôt et à la diffusion de documents scientifiques de niveau recherche, publiés ou non, émanant des établissements d'enseignement et de recherche français ou étrangers, des laboratoires publics ou privés. 
Assessment of seasonal variability of biomarkers in three-spined stickleback (Gasterosteus aculeatus L.) from a low contaminated stream : implication for environmental biomonitoring

Wilfried Sanchez ${ }^{1 *}$, Benjamin Piccini ${ }^{1}$, Jean-Maxence Ditche ${ }^{2}$, Jean-Marc Porcher ${ }^{1}$

${ }^{1}$ Institut National de l'Environnement Industriel et des Risques (INERIS), Unité d'Evaluation des Risques Ecotoxicologiques, BP2, 60550, Verneuil-en-Halatte, France

${ }^{2}$ Office National de l'Eau et des Milieux Aquatiques, 60200 Compiègne, France

* Corresponding author. Tel : +33 (0)3 44618121 ; Fax: +33 (0)3 44556767

E-mail address : Wilfried.Sanchez@ineris.fr (W.Sanchez) 


\begin{abstract}
In this study, wild three-spined sticklebacks were sampled every six weeks, between April and October, in a low contaminated stream. For all fish, physiological indexes, such as condition factor, hepato-, gonado- and nephro-somatic index were calculated to determine fish condition and reproductive status. Moreover, a set of biomarkers including biotransformation enzymes, oxidative stress parameters, neurotoxicity and endocrine disruption markers was measured. The results allowed to determine biomarker variability due to fish gender or sampling season. For example, 7-ethoxyresorufin-O-deethylase activity, glutathione peroxidase as well as vitellogenin and spiggin exhibited strong gender differences. Conversely, lipoperoxidation and acethylcholinesterase activity were characterised by a lack of gender and seasonal variation, and can be considered as more robust parameters for a field application. The present work allowed to establish practical guideline for biomarker measurements in wild sticklebacks and to define a reference system which can be used to analyze variations in future monitoring studies.
\end{abstract}

Key-words : biomarker, fish, three-spined stickleback, biomonitoring, reference, seasonal variability, basal level. 


\section{Introduction}

Biomarkers have been defined as a change in biological response which can be related to exposure or toxic effect of environmental chemicals (Peakall, 1994) and they have been proposed as sensitive tools for early detection of environmental exposure and adverse effects of pollutants on aquatic organisms. In this context, many parameters are investigated to assess disturbances of various physiological functions linked to chemical exposure and/or effects (for review, see Van der Oost et al., 2003). However, there is no single biomarker that can unequivocally measure environmental degradation. This problem is solved by the use of a set of complementary biomarkers, a methodological approach that is now widely recognized for environmental biomonitoring (Galloway et al., 2004; Triebskorn et al., 2001).

Several biotic (species, sex, reproductive status, parasites) and abiotic (water temperature, food availability) natural factors are known to modulate biomarker responses (Martinez-Alvarez et al., 2005; Whyte et al., 2000). These confounding factors make it difficult to interpret the different variation levels between sampling sites and prevent the extensive utilization of biomarkers for environmental risk assessment. In a practical way, several methods allow to reduce variability for a better application of biomarkers in a biomonitoring context. (1) Part of biomarker variability can be explained by the sampling regime itself. This could be reduced by an optimisation of sampling conditions (i.e. sampling during a short period, reduction of fish size range, increase of fish numbers)(Payne et al., 1996). (2) A better characterisation of confounding factors such as physicochemical parameters in water and reproductive status of fish, could allow to explain the observed variability and to discriminate responses induced by pollutant exposure and background noise using appropriate statistical analysis (Sturm et al., 1999). (3) Data normalisation could also allow reducing biomarker variability as previously reported for gender differences in EROD activity (Flammarion et al., 1998). Hence, the application of biomarkers for environmental monitoring requires an extensive knowledge of natural variability of biomarkers. Moreover, biomonitoring data 
interpretation and accurate description of effects recorded in situ requires the availability of valuable reference values (Nixon et al., 1996). Classically, field studies based on biomarker measurement consider upstream-downstream comparisons to assess the effects of a specific point or of the water quality for a stream (Machala et al., 2000; Stanic et al., 2006; Vigano et al., 1998). If suitable upstream values are not available, it might be of great interest to assess biomarker responses in contaminated streams in relation to background levels recorded in clean areas which may be accepted as reference values of fish biomarkers (Flammarion and Garric, 1997; Mayon et al., 2006). To characterise biomarker seasonal variations and determine reference values in aquatic organisms, sampling at various seasons during one year appears as a useful methodological approach (Larsen et al., 1992; Lau et al., 2004). However, in biomonitoring studies, winter is frequently excluded for practical reasons such as fish sampling difficulties and low level of biomarker responses. Hence, sampling period between spring and autumn is currently recommended (Flammarion and Garric, 1997).

The three-spined stickleback (Gasterosteus aculeatus L.) is used as biological model. This fish species has been recently pointed out as a valuable sentinel fish species to assess fish health and pollution in European aquatic ecosystems (Handy et al., 2002; Sanchez et al., 2007; Sturm et al., 2000). Indeed, the stickleback inhabits most streams, small rivers, estuarian and coastal areas in Europe where it is encountered in both clean and polluted areas (Wootton, 1976). Moreover, this fish species is characterised by a stationary behaviour, hence the observed responses could reflect the local environment and the biochemical responses are sensitive enough to assess sublethal stress in multipollution context (Sanchez et al., 2007).

This study was designed to provide information on stickleback biomarker variability due to biotic and abiotic factors and also to establish practical guideline for biomarker measurements in wild sticklebacks. On the other hand, this work allowed to obtain preliminary information about endogenous levels of biomarkers in stickleback, in order to define a reference system which can be 
used to analyze biomarker responses measured in fish from polluted sites. For this purpose, male and female adult sticklebacks were sampled six fold between April and October 2007 from a site considered as lowly contaminated. To assess the low contamination level of selected sampling site, physico-chemical properties of water, as well as chemical contamination of water and sediment were considered. Moreover, in all fish, physiological index (i.e. condition factor : CF, and liver, gonad and kidney somatic index : LSI, GSI and NSI respectively) and biochemical biomarkers were measured. The investigated biomarkers were related to xenobiotic metabolism (i.e. 7ethoxyresorufin-O-deethylase [EROD] and glutathione-S-transferase [GST]) and oxidative stress (i.e. glutathione peroxidase [GPx], total glutathione content [GSH] and lipoperoxidation [TBARS]), but also to neurotoxicity (i.e. acetylcholinesterase $[\mathrm{AChE}]$ ) and endocrine disruption (i.e. vitellogenin [VTG] and spiggin $[\mathrm{SPG}])$.

\section{Materials and methods}

\subsection{Sampling site}

The French site of Vallon du Vivier (VDV : 49 43' 23" N, $0^{\circ} 27^{\prime} 42^{\prime \prime}$ E) was selected to assess seasonal variability of biochemical biomarkers in stickleback. This sampling site was located in the upper area of a stream submitted to a mixed environmental pressure (EEA, 2001) but no point source of chemical pollutants was known at this location. Fish species encountered in this site such

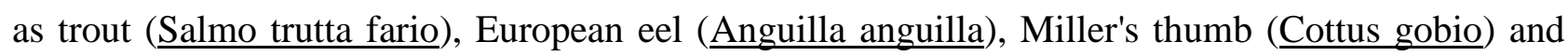
stickleback were in accordance with characteristic fish assemblage of trout area as described by Huet (1949). Hence, the Fish-Based Index value determined according to Oberdorff et al. (2002), was one, thus indicating a lack of disturbance of fish assemblage compared to reference determined for this stream class. In light of this information, VDV site was considered as a potential reference site for the purpose of the present work. 


\subsection{Environmental parameters and chemical analysis in water and sediment}

Water physicochemical parameters including temperature, $\mathrm{pH}$, dissolved oxygen concentration, conductivity and hardness, were recorded directly during fish collection. For all sampling period, concentration of cadmium $(\mathrm{Cd})$, chromium $(\mathrm{Cr})$, copper $(\mathrm{Cu})$, lead $(\mathrm{Pb})$, nickel $(\mathrm{Ni})$, selenium $(\mathrm{Sn})$ and zinc $(\mathrm{Zn})$ were measured on the dissolved fraction of water by Inductively Coupled Plasma / Mass Spectrometry (ICP/MS) according to the standard NF EN ISO 17294. The limit of detection for heavy metals in water was $0.09 \mu \mathrm{g} / \mathrm{L}$. Twenty five pesticides (Table 1) were determined using a multiresidue analysis on a gas-chromatograph coupled with a mass spectrometer (GS-MS). Prior GC-MS analysis, a liquid-solid extraction was performed using styrene/dimethylbenzene (Chromabond) as solid phase and dichloromethane/acetone as liquid phase. GC-MS consisted of a TurboMass Gold (Perkin Helmer). Samples were injected $(1 \mu \mathrm{L})$ in a 50 meter chromatographic column containing $5 \%$ phenyl $95 \%$ dimethylpolysiloxane with helium as carrier gas. The initial temperature of $50^{\circ} \mathrm{C}$ was increased to $320^{\circ} \mathrm{C}$. The detection limit for pesticides in water was 0.05 $\mu \mathrm{g} / \mathrm{L}$.

Sixteen PAHs defined as prioritary by United States Environmental Protection Agency (US EPA), PCBs $\mathrm{n}^{\circ} 28,52,101,118,138,153,180$ and twenty five pesticides (Table 1 ) were determined in sediment extracts using a multiresidue procedure. Sample preparation was performed on an ASE 300 system (Dionex). $10 \mathrm{~g}$ of sediments were mixed with $5 \mathrm{~g}$ of Celite and extracted using dichloromethane. The collected extracts were evaporated using nitrogen flux and resuspended in methanol. After extract purification by Fluoresil, organic compounds were analysed using the same GC-MS method previously described. The detection limits in sediment were $50 \mathrm{mg} / \mathrm{kg}$ for pestides and $20 \mathrm{mg} / \mathrm{kg}$ for PCBs and PAHs.

\subsection{Fish collection and tissue sampling}


Three-spined sticklebacks were electrofished every six weeks from April to October 2006. Fish ranging from 35 to $56 \mathrm{~mm}$ were selected to measure biochemical parameters (16-30 fish/month). After capture, fish were weighed, measured and immediately sacrificed. Blood was collected, diluted 4-fold in phosphate buffer (100 mM, pH 7.8) with $0.2 \mathrm{mM}$ phenylmethylsulfonyl fluoride (PMSF) as a serine protease inhibitor and stored in liquid nitrogen prior VTG analysis. Liver, gonad, kidney and muscle were rapidly dissected, weighed and frozen in liquid nitrogen prior to homogenisation and biochemical analysis.

For all fish, the condition factor (CF) was calculated according to Pottinger et al. (2002), while somatic indexes for liver, gonads and kidney (HSI, GSI and NSI respectively) were calculated as (organ weight / fish weight) x 100 .

\subsection{Biomarker analysis}

Livers and muscle were homogenised in ice-cold phosphate buffer (100 mM, pH 7.8) with 20\% glycerol and 0.2 mM PMSF. The homogenates were centrifuged at $10,000 \mathrm{~g}, 4^{\circ} \mathrm{C}$, for $15 \mathrm{~min}$ and the supernatants that represented postmitochondrial fraction were used for biochemical assays. Total protein concentrations were determined using the method of Bradford (1976) with bovine serum albumin (Sigma-Aldrich Chemicals, France) as a standard. Hepatic biomarker assays including EROD, GST, GPx, GSH and TBARS were conducted, respectively, according to the methods of Flammarion et al. (1998), Habig et al. (1974), Paglia and Valentine (1967), Vandeputte et al. (1994) and Ohkawa et al. (1979) adapted in microplate and optimised for stickleback as previously described by Sanchez et al. (2005b ; 2007). AChE activity was measured in muscle according to the method developed by Sturm et al. (2000) using tetraisopropyl pyrophosphoramide as butyrylcholinesterase inhibitor. Concentrations of VTG in total blood was measured according to the method described by Sanchez et al. (2005a). This assay is based on a competition for the antiVTG antibodies (GA-306, Biosense Laboratories, Bergen, Norway) diluted to 1:1,000 between 
standard-VTG coated on the wells of a microtiter plate at $25 \mathrm{ng} / \mathrm{mL}$ and free VTG in the sample or standard solutions. The detection limit for VTG in a blood sample is $256 \mathrm{ng} / \mathrm{mL}$. SPG in kidney was measured, after dissolution process, by specific competitive ELISA described by Sanchez et al. (2008). The detection limit for SPG in a kidney sample is $12.5 \mathrm{U} / \mathrm{mL}$.

\subsection{Statistical analysis}

All data are reported as mean \pm standard deviation and SPSS 14.0 software was used for statistical analysis. Firstly time, normal distribution and homoscedasticity of data were verified using Kolmogorrov-Smirnov and Levene tests respectively $(\alpha=0.05)$. As data sets had not a normal distribution and/or homogeny variance, biomarker data were log-transformed, using $\mathrm{F}(\mathrm{x})=$ $\log (1+\mathrm{x})$, prior to parametric analysis. Secondly, a two-way analysis if variance (ANOVA) was performed, for each physiological parameter and biomarker, using sampling month and fish gender as factors. When month by gender interaction was significant $(\alpha=0.05)$, male and female data were treated separately (HSI, GSI, NSI and also EROD, GPx, VTG and SPG). Mean values recorded at each sampling period for all investigated parameters were compared using one-way ANOVA followed by Sidak test $(\alpha=0.05)$.

\section{Results}

\subsection{Sampling site characterisation}

Physico-chemical parameters measured in water at all sampling periods were characterised by a low variability (Table 2). Moreover, the values noticed for each parameter reflected a good water quality compared to the values described by the French water quality evaluation system (Simonet, 2001) and the European water framework directive (European Commission, 2000). The good water quality in this site was confirmed by metal and pesticide analysis. Chromium, copper, nickel, lead and zinc were quantified (Table 2) but the measured values were in accordance with the good 
chemical status described in the European water framework directive (European Commission, 2000). Moreover, no pesticides researched in water were detected at all sampling periods (Table 2). In sediments, no PCB and pesticides were detected (Table 3). Among the investigated PAHs, naphthalene, acenaphthylene, acenaphthene and fluorene were not detected. The other measured PAHs were quantified (Table 3) and the concentration of all PAHs in sediment was approximately $1 \mathrm{mg} / \mathrm{kg}$.

\subsection{Physiological and biochemical parameters}

Sticklebacks caught in this study are above $35 \mathrm{~mm}$ of length and can be considered as adult and mature fish (Jones and Hynes, 1950; Roussel et al., 2007). During the first three months (i.e. April, May and June), males expressed nuptial coloration and females showed ovaries containing large oocytes that reflected the breeding status of fish during this period. The results for physiological and biochemical parameters are presented in Tables 4 and 5 respectively. In these tables, males and females are presented separately when significant differences were revealed by two-way ANOVA performed using sampling period and fish gender as co-factors for each parameters.

Except for CF, all physiological indexes investigated in this study showed significant gender differences. Moreover, somatic index variations between sampling periods were also noticed. During the reproductive period (April-June), male fish were characterised by an high NSI. In the same period, females exhibited high GSI and HSI values but no significant variation of NSI. These results pointed out the strong implication of these organs in reproductive function of stickleback (Table 4).

EROD and GPx appeared as gender-dependent parameters with high EROD and low GPx activities in male fish compared to female. For other investigated parameters, no significant difference was noticed between both gender (Table 5). The assessment of seasonal variations showed that EROD activity in females was lower during the first three months compared to others. For this same 
period, GPx activity measured in male fish appears as decreased and a depletion of total GSH content was also noticed. A decrease of GST activity was also recorded in May. In this study, TBARS and AChE appeared not to be influenced by seasonal variation (Table 5). Endocrine disruption biomarkers as VTG and SPG were assessed in both fish gender. These parameters were expressed only during the breeding period, in females and males respectively, and exhibited a decrease trend in June (Table 5). However, we recorded a strong variability of VTG and SPG expression as indicated by high standard deviation values that reflects inter-individual variability of these biomarkers.

\section{Discussion}

The accurate interpretation of biomarker data in a biomonitoring context requires a valuable control area for biomarker measurements (Nixon et al., 1996). The choice of reference sampling site proves to be very difficult as few media are free of chemical contamination (Lindström-Seppa and Oikari, 1990). To solve this problem, three practical ways can be used including fish collection upstream to investigated area (Machala et al., 2000; Vigano et al., 1998), previous fish collection in the same site, or investigation in a low contaminated site unlinked to other investigated sites (Aarab et al., 2004; Mayon et al., 2006). The applied methodology is chosen according to the experimental objectives. The aim of this work was to examine the seasonal variation of biomarker basal levels and to collect preliminary information to establish physiological values for wild stickleback. Hence, we selected a site located in the study area used for our previous works (Sanchez et al., 2007; Sanchez et al., in press) and characterized by a low level of contamination as indicated by chemical analysis performed in water and sediment.

Condition factor and somatic indexes provide a valuable information on fish physiological status. $\mathrm{CF}$ is an indicator of fish shape and energy reserves. Hence, various factors such as physiological development, food availability, parasites but also chemical contamination can influence this 
parameter (Eastwood and Couture, 2002; Pottinger et al., 2002). In the present work, no seasonal variation of CF was observed. This result is in accordance with the results of Roussel et al. (2007) that showed also a lack of CF difference for sticklebacks caught in outdoor lotic mesocosms. Hence, in this fish species, CF can be considered as robust parameter to biotic and abiotic factors. Also, CF variations linked to water pollution have been previously described in stickleback collected at French contaminated streams (Sanchez et al., 2007) and showed that this metric can inform on physiological effect of water contaminants. Somatic indexes calculated for various organs (i.e. liver, gonad, kidney) reflect their metabolic activity. In addition, HSI, GSI and NSI exhibited strong gender differences as well as strong seasonal variability. According to the observations of Sokolowska et al. (2004), female sticklebacks exhibited elevated HSI and GSI values during breeding period that can be linked respectively to liver implication in vitellogenesis and maturation of oocytes in ovaries. An increase of male NSI linked to kidney hypertrophy in the phase of nest building, was also noticed during this period. The somatic indexes measured here allow to characterise reproductive status of stickleback and show that fish collected between April and July were in an active reproductive status according to the field observations (i.e. nuptial coloration in males and oocytes in female ovaries). Because of the liver's role in storage and metabolism, nutritional quality and regimes also affect relative liver size (Foster et al., 1993) and could explain the variations observed outside of breeding period.

Constitutive levels of biochemical parameters and their responses under pollution effects are also known to be influenced by reproductive season. In the present study, we showed that stickleback EROD activity is a gender-dependent parameter with higher activity in males than in females during breeding period. A similar phenomenon was previously reported in many fish species such as chub, gudgeon (Flammarion and Garric, 1997) and flounder (Kirby et al., 2004) and could be explained by the negative effect of endogenous estradiol on cytochrome P-450 catalytic activity (Arukwe and Goksøyr, 1997). However, a recent paper showed that EROD suppression in female 
sticklebacks exposed to ethynylestradiol could be due to protein dilution generated by vitellogenesis (Andersson et al., 2007). Hence, this phenomenon could also explain the gender difference of EROD noticed during reproductive period. Also we reported that enzymatic antioxidant GPx is a gender-dependent biomarker in stickleback. Similar phenomenon have been previously reported in other fish species such as brown bullhead (Mc Farland et al., 1999) and eelpout (Ronisz et al., 1999). No mechanism is known in fish to explain this male-female variation. Nevertheless, GPx activity variations linked to gender of mammals have been reported (Burk et al., 1980) and the authors suggested that higher GPx activity in female rats was due to the implication of this enzyme in female hormone metabolism. A similar mechanism could explain the gender variation of GPx in stickleback and is consistent with the more marked difference recorded during spawning period in this study and in previous experiments (Sanchez et al., 2007).

Other environmental factors may affect physiological levels of biomarkers and could also explain a part of variations observed especially for antioxidant parameters (i.e. GPx, GSH but also GST). Among these factors, food availability is well known to modify antioxidant levels as indicated in a previous study that reported disturbance of GSH redox status and increase of antioxidant activities in immature gilthead seabreams ( parus aurata) maintained for 46 days under food restriction (Pascual et al., 2003). Diet composition appears also as an important confounding factor. Indeed, levels of lipids and vitamins influence oxidative status as pointed out by several studies that show a protective effect of lipid and vitamin rich diets (Mourente et al., 2000; Mourente et al., 2002). Dissolved oxygen concentration is also a parameter described as able to modulate antioxidant activities (Cooper et al., 2002; Lushchak et al., 2001). In the investigated site, oxygen concentration is high (i.e. 8.7 to $11.8 \mathrm{mg} / \mathrm{L}$ ) during all sampling campaign but the decrease measured in June could explain a part of biomarker variations and especially the GSH increase noticed at this time. Hence, in light of previous laboratory observations that showed strong variability of antioxidant parameters in stickleback (Sanchez et al., 2005b; 2006), the present results argue for a better 
characterisation of environmental parameters able to influence biomarker levels that will allow a good evaluation of biomarker variations.

Among the investigated biochemical markers, TBARS and AChE showed a lack of gender effect and seasonal variation. These results were in accordance with data previously reported in wild sticklebacks that showed a lack of significant differences for both biomarkers measured in Spring, Summer and Autumn (Sanchez et al., 2007; Sturm et al., 1999). Moreover, Sturm et al. (1999) highlighted that AChE activity measured in wild fish is not dependent on water quality parameters such as temperature, $\mathrm{pH}$, dissolved oxygen or hardness. Hence, these results pointed out the robustness of these biomarkers that could be used indifferently in both gender at all sampling period.

The variation profiles recorded for VTG and SPG showed that both endocrine disruption biomarkers were expressed only during the breeding period in fish gender that physiologically synthesises these proteins. This result was consistent with high values of HSI and NSI respectively recorded in female and male fish that can be due to protein synthesis (Andersson et al., 2007; Sanchez et al., 2008). However, during the breeding period, the over-expression of VTG and SPG and the high variability of these parameters prevent their utilization in the gender that expresses naturally these proteins as previously revealed for VTG in dab (Limanda limanda) collected in UK offshore waters (Scott et al., 2007). Conversely, the results of the present study showed that during all sampling period, VTG and SPG were not detected in males and females respectively. Hence, in stickleback, these biomarkers appear as valuable parameters to monitor aquatic ecosystem contamination respectively by estrogenic and androgenic endocrine-disrupting chemicals throughout the year. Moreover, outside stickleback breeding period, VTG and SPG were not detected in both gender. Therefore, male and female fish could be used without distinction when collected sticklebacks are not in reproductive phase and consequently, the number of collected fish could be reduced. 


\section{Conclusion}

This study was designed to provide valuable knowledge on basal levels of stickleback biomarkers and their natural variations. For this purpose, adult sticklebacks were collected, during six months, in a site characterised by a good water quality and an undisturbed fish assemblage. Our results show that season and associated environmental factors can influence stickleback biochemical marker levels and allow to establish practical recommendations for stickleback biomarker-based biomonitoring.

- EROD activity exhibited a strong gender effect during the breeding period that prevents the extensive utilisation of this biomarker. In light of the results presented in this study, three practical ways can be considered for the application of EROD measurement in a biomonitoring context including investigation in male only, measurement in both gender during the non reproductive period, or data normalisation to correct gender differences as previously described by Flammarion et al. (1998).

- A part of variation recorded for oxidative stress biomarkers (i.e. GPx, GSH and GST) cannot be explained by gender or season and could be linked to modification of food availability or other environmental factors. Hence, the interpretation of the responses of these biomarkers in a biomonitoring context appears difficult and requires an accurate well characterisation of sampling site.

- The lack of seasonal variability for TBARS and AChE point out these parameters as robust biomarkers that can be used indifferently at all sampling seasons.

- During reproductive period, VTG and SPG showed a strong gender difference due to the physiological function of these proteins but only fish expressing naturally these markers (i.e. female for VTG and male for SPG) present detectable concentrations. Conversely, outside breeding period, these proteins are not detected in both fish gender, hence, male and female 
sticklebacks could be used without distinction for the measurement of endocrine disruption biomarkers.

Partly because the present study lasted only 6 months, some parameters which are known to influence biomarker responses such as temperature and dissolved oxygen concentration exhibited low variation. Hence, further multi-annual experiments are needed to characterise accurately the natural variability of biomarkers in stickleback.

Temporal response profiles recorded here allow a first determination of biomarker basal levels inside and outside breeding period as summarised in Table 6. This data set could be used for a better interpretation of biomarker responses in wild stickleback. However, the present work was performed in a single site located in the "Tables calcaires" hydro-ecoregion in the North of France (Wasson et al., 2002). Hence, further field experiments based on combination between biochemical measurements and determination of physiological, morphological and genetic parameters, are needed to determine the geographical validity of these basal levels and to establish appropriate units of management.

\section{Acknowledgements}

We thank the official fishguards from the "Office National de l'Eau et des Milieux Aquatiques " for the technical assistance in fish sampling. We thank also the staff from environmental chemistry unit of INERIS, namely K. Tack and L. Meunier for metal analysis in surface water, O. Diago for sediment extraction, D. Debrun from the Laboratoire Départemental d'Analyses de l'Oise (France) for organic chemical analysis but also J. Sabarly for reviewing this manuscript. This work was supported by the French Ministry of Ecology and Sustainable Development (Budget Civil de la Recherche et du Développement AP-2004) and the "région Picardie".

\section{References}


Aarab, N.; Champeau, O.; Mora, P.; Daubeze, M.; Garrigues, P.; Narbonne, J.F. Scoring approach based on fish biomarkers applied to French river monitoring. Biomarkers 9: 258-270; 2004.

Andersson, C.; Katsiadaki, I.; Lundstedt-Enkel, K.; Orberg, J. Effects of 17[alpha]-ethynylestradiol on EROD activity, spiggin and vitellogenin in three-spined stickleback (Gasterosteus aculeatus). Aquat. Toxicol. 83: 33-42; 2007.

Arukwe, A.; Goksøyr, A. Changes in three hepatic cytochrome P450 subfamilies during a reproductive cycle in turbot (Scophthalmus maximus L.). J. Exp. Zool. 277: 313-325; 1997.

Bradford, M.M. A rapid sensitive method for the quantitation of microgram quantities of protein utilizing the principle of protein-dye binding. Anal. Biochem. 72: 248-254; 1976.

Burk, R.F.; Lawrence, R.A.; Correia, M.A. Sex differences in biochemical manifestations of selenium deficiency in rat liver with special reference to heme metabolism. Biochem. Pharmacol. 29: $39-42 ; 1980$.

Cooper, R.U.; Clough, L.M.; Farwell, M.A.; West, T.L. Hypoxia-induced metabolic and antioxidant enzymatic activities in the estuarine fish Leiostomus xanthurus. J. Exp. Mar. Biol. Ecol. 279: 1-20; 2002.

Eastwood, S.; Couture, P. Seasonal variations in condition and liver metal concentrations of yellow perch (Perca flavescens) from a metal-contaminated environment. Aquat. Toxicol. 58: 43-56; 2002.

EEA. Reporting river quality using the Water Quality Accounts methodology. Application within the Eurowaternet process, Copenhagen, pp. 24; 2001.

European Commission. Directive 2000/60/EC of the European Parliament and of the Council of 23 October 2000 establishing a framework for Community action in the field of water policy. The European Parliament and Council, L327/1, 2000, pp. 72; 2000. 
Flammarion, P.; Garric, J. Cyprinids EROD activities in low contaminated rivers: a relevant statistical approach to estimate reference levels for EROD biomarker? Chemosphere 35: 2375$2388 ; 1997$.

Flammarion, P.; Migeon, B.; Garric, J. Statistical Analysis of Cyprinid Ethoxyresorufin-Odeethylase Data in a Large French Watershed. Ecotoxicol. Environ. Saf. 40: 144-153; 1998.

Foster, A.R.; Houlihan, D.F.; Hall, S.J. Effects of nutritional regime on correlates of growth rate in juvenile Atlantic cod (Gadhus morhua): comparisons of morphological and biochemical measurements. Can. J. Fish. .Aquat. Sci. 50: 502-512; 1993.

Galloway, T.S.; Brown, R.J.; Browne, M.A.; Dissanayake, A.; Lowe, D.; Jones, M.B.; Depledge, M.H. A multibiomarker approach to environmental assessment. Environ. Sci. Technol. 38: 1723$1731 ; 2004$.

Habig, W.H.; Pabst, M.J.; Jakoby, W.B. Glutathione S-Transferases. The first enzymatic step in mercapturic acid formation. J. Biol. Chem. 249: 7130-7139;1974.

Handy, R.D.; Runnalls, T.; Russel, P.M. Histopathologic biomarkers in three spined sticklebacks, Gasterosteus aculeatus, from several rivers in Southern England that meet the freshwater fisheries directive. Ecotoxicology 11: 467-479; 2002.

Huet, M. Aperçu des relations entre la pente et les populations piscicoles des eaux courantes. Schweiz. Z. Hydrol. I1: 332-351; 1949.

Jones, J.W.; Hynes, H.B.N. The age and growth of Gasterosteus aculeatus and , Pigosteus oungitius and Spinachia vulgaris, as shown by their otoliths. J. Anim. Ecol. 19: 59-73; 1950.

Kirby, M.F.; Neall, P.; Bateman, T.A.; Thain, J.E. Hepatic ethoxyresorufin O-deethylase (EROD) activity in flounder (Platichthys flesus) from contaminant impacted estuaries of the United Kingdom: continued monitoring 1999-2001. Mar. Pollut. Bull. 49: 71-78; 2004. 
Larsen, H.E.; Celander, M.; Goksoyr, A. The cytochrome P450 system of Atlantic salmon (Salmo salar): II. Variations in hepatic catalytic activities and isozyme patterns during an annual reproductive cycle. Fish Physiol. Biochem. 10: 291-301; 1992.

Lau, P.S.; Wong, H.L.; Garrigues, P. Seasonal variation in antioxidative responses and acetylcholinesterase activity in perna viridis in eastern oceanic and western estuarine waters of Hong Kong. Cont. Shelf Res. 24: 1969-1987; 2004.

Lindström-Seppa, P.; Oikari, A. Biotransformation activities of feral fish in waters receiving bleached pulp mill effluents. Environ. Toxicol. Chem. 9: 1415-1424; 1990.

Lushchak, V.I.; Lushchak, L.P.; Mota, A.A.; Hermes-Lima, M. Oxidative stress and antioxidant defenses in goldfish Carassius auratus during anoxia and reoxygenation. Am. J. Physiol. 280: R100-R107; 2001.

Machala, M.; Ulrich, R.; Neca, J.; Vykusova, B.; Kolarova, J.; Machova, J.; Svobodova, Z. Biochemical monitoring of aquatic pollution: Indicators of dioxin-like toxicity and oxidative stress in the roach (Rutilus rutilus) and chub (Leuciscus cephalus) in the Skalice river. Vet. Med.-Czech. 45: 55-60; 2000.

Martinez-Alvarez, R.M.; Morales, A.E.; Sanz, A. Antioxidant defenses in fish : biotic and abiotic factors. Rev. Fish Biol. Fish. 15: 75-88; 2005.

Mayon, N.; Bertrand, A.; Leroy, D.; Malbrouck, C.; Mandiki, S.N.M.; Silvestre, F.; Goffart, A.; Thome, J.-P.; Kestemont, P. Multiscale approach of fish responses to different types of environmental contaminations: A case study. Sci. Total Environ. 367: 715-731; 2006.

Mc Farland, V.A.; Inouye, L.S.; Jarvis, A.S.; Clarke, J.U.; Mc Cant, D.D. Biomarkers of oxidative stress and genotoxicity in livers of field-collected brown bullhead, Ameiurus nebulosus. Arch. Environ. Contam. Toxicol. 37: 236-241; 1999. 
Mourente, G.; Diaz-Salvago, E.; Tocher, D.R.; Bell, J.G. Effects of dietary polyunsaturated fatty acid/vitamin E (PUFA/tocopherol ratio on antioxidant defence mechanisms of juvenile gilthead sea bream (Sparus aurata L., Osteichthyes, Sparidae). Fish Physiol. Biochem. 23: 337-351; 2000.

Mourente, G.; Diaz-Salvago, E.; Bell, J.G.; Tocher, D.R. Increased activities of hepatic antioxidant defence enzymes in juvenile gilthead sea bream (Sparus aurata L.) fed dietary oxidised oil: attenuation by dietary vitamin E. Aquaculture 214: 343-361; 2002.

Nixon, S.C.; Mainstone, C.P.; Iversen, T.M.; Kristensen, P.; Jeppesen, E.; Papathanassiou, E.; Jensen, A.; Pedersen, F. The harmonised monitoring and classification of ecological quality of surface waters in the European union. Final report. WRc Ref CO 4150, pp. 289; 1996.

Oberdorff, T.; Pont, D.; Hugueny, B.; Belliard, J.; Berrebi Dit Thomas, R.; Porcher, J.P. Adaptation et validation d'un indice poisson (FBI) pour l'évaluation de la qualité biologique des cours d'eau français. Bull. Fr. Pêche Piscic. 365/366: 405-433; 2002.

Ohkawa, H.; Ohishi, N.; Yagi, K. Assay for lipid peroxides in animal tissues by thiobarbituric acid reaction. Anal. Biochem. 95: 351-358; 1979.

Paglia, D.E.; Valentine, W.N. Studies on the quantitative and qualitative characterization of erythrocyte glutathione peroxidase. J. Lab. Clin. Med. 70: 158-169; 1967.

Pascual, P.; Pedrajas, J.R.; Toribio, F.; Lopez-Barea, J.; Peinado, J. Effect of food deprivation on oxidative stress biomarkers in fish (Sparus aurata). Chem.-Biol. Interact. 145: 191-199; 2003.

Payne, J.F.; Mathieu, A.; Melvin, W.; Fancey, L.L. Acetylcholinesterase, an old biomarker with a new future? Field trials in association with two urban rivers and a paper mill in Newfoundland. Mar. Pollut. Bull. 32: 225-231; 1996.

Peakall, D.W. Biomarkers: the way forward in environmental assessment. Toxicology and Ecotoxicology News 1: 55-60; 1994.

Pottinger, T.G.; Carrick, T.R.; Yeomans, W.E. The three-spined stickleback as an environmental sentinel: effects of stressors on whole-body physiological indices. J. Fish Biol. 61: 207-229; 2002. 
Ronisz, D.; Larsson, D.G.J.; Forlin, L. Seasonal variations in the activities of selected hepatic biotransformation and antioxidant enzymes in eelpout (Zoarces viviparus). Comp. Biochem. Phys. C 124: 271-279; 1999.

Roussel, H.; Joachim, S.; Lamothe, S.; Palluel, O.; Gauthier, L.; Bonzom, J.-M. A long-term copper exposure on freshwater ecosystem using lotic mesocosms: Individual and population responses of three-spined sticklebacks (Gasterosteus aculeatus). Aquat. Toxicol. 82: 272-280; 2007. Sanchez, W.; Brion, F.; Nilsen, B.M.; Porcher, J.M. Assessment of estrogenic effects in the threespined stickleback (Gasterosteus aculeatus L.) using vitellogenin measurement by ELISA method, 15th annual meeting of Society of Environmental Toxicology and Chemistry, Lille, France; 2005 . Sanchez, W.; Palluel, O.; Lagadic, L.; Aït-Aïssa, S.; Porcher, J.-M. Biochemical effects of nonylphenol polyethoxylate adjuvant, Diquat herbicide and their mixture on the three-spined stickleback (Gasterosteus aculeatus L.). Mar. Environ. Res. 62: S29-S33; 2006.

Sanchez, W.; Aït-Aïssa, S.; Palluel, O.; Ditche, J.M.; Porcher, J.M. Preliminary investigation of multi-biomarker responses in three-spined stickleback (Gasterosteus aculeatus L.) sampled in contaminated streams. Ecotoxicology 16: 279-287; 2007.

Sanchez, W.; Katsiadaki, I.; Piccini, B.; Ditche, J.M.; Porcher, J.M. Multi-biomarker responses in wild three-spined stickleback (Gasterosteus aculeatus L.) as a useful tool for freshwater biomonitoring : a multiparametric approach. Environ. Pollut. in press.

Sanchez, W.; Palluel, O.; Meunier, L.; Coquery, M.; Porcher, J.-M.; Aït-Aïssa, S. Copper-induced oxidative stress in three-spined stickleback: relationship with hepatic metal levels. Environ. Toxicol. Pharmacol. 19: 177-183; $2005 b$.

Sanchez, W.; Goin, C.; Brion, F.; Olsson, P.E.; Goksøyr, A.; Porcher, J.M. A new ELISA for the three-spined stickleback (Gasterosteus aculeatus L.) spiggin, using antibodies against synthetic peptide. Comp. Biochem. Physiol. C 147: 129-137; 2008. 
Scott, A.P.; Sanders, M.; Stentiford, G.D.; Reese, R.A.; Katsiadaki, I. Evidence for estrogenic endocrine disruption in an offshore flatfish, the dab (Limanda limanda L.). Mar. Environ. Res. 64: 128-148; 2007.

Simonet, F. Le nouveau système d'évaluation de la qualité de l'eau des rivières : le SEQ-Eau. Revue de l'agence de l'eau Adour Garonne 81: 7-9; 2001.

Sokolowska, E.; Kalamarz, H.; Kulczykowska, E. Seasonal changes in brain melatonin concentration in the three-spined stickleback (Gasterosteus aculeatus): towards an endocrine calendar. Comp. Biochem. Physiol. A 139: 365-369; 2004.

Stanic, B.; Andric, N.; Zoric, S.; Grubor-Lajsic, G.; Kovacevic, R. Assessing pollution in the Danube River near Novi Sad (Serbia) using several biomarkers in sterlet (Acipenser ruthenus L.). Ecotoxicol. Environ. Saf. 65: 395-402; 2006.

Sturm, A.; Wogram, J.; Hansen, P.D.; Liess, M. Potential use of cholinesterase in monitoring low levels of organophosphates in small streams: natural variability in three-spined stickleback (Gasterosteus aculeatus) and relation to pollution. Environ. Toxicol. Chem. 18: 194-200; 1999.

Sturm, A.; Wogram, J.; Segner, H.; Liess, M. Different sensitivity to organophosphates of acetylcholinesterase and butyrylcholinesterase from three-spined stickleback (Gasterosteus aculeatus): application in biomonitoring. Environ. Toxicol. Chem. 19: 1607-1615; 2000.

Triebskorn, R.; Böhmer, J.; Braunbeck, T.; Honnen, W.; Köhler, H.-R.; Lehmann, R.; Oberemm, A.; Schwaiger, J.; Segner, H.; Schüürmann, G.; Traunspurger, W. The project VALIMAR (VALIdation of bioMARkers for the assessment of small stream pollution): objectives, experimental design, summary of results, and recommendations for the application of biomarkers in risk assessment. J. Aquat. Ecosyst. Stress and Recovery 8: 161-178; 2001. Van der Oost, R.; Beyerb, J.; Vermeulen, N. Fish bioaccumulation and biomarkers in environmental risk assessment: a review. Environ. Toxicol. Pharmacol. 13: 57-149; 2003. 
Vandeputte, C.; Guizon, I.; Genestie-Denis, I.; Vannier, B.; Lorenzon, G. A microtiter plate assay for total glutathione and glutathione disulfide contents in cultured/isolated cells: performance study of a new miniaturized protocol. Cell Biol. Toxicol. 10: 415-421; 1994.

Vigano, L.; Arillo, A.; Melodia, F.; Arlati, P.; Monti, C. Biomarker responses in cyprinids of the middle stretch of the river Po, Italy. Environ. Toxicol. Chem. 17: 404-411; 1998.

Wasson, J.G.; Chandesris, A.; Pela, H.; Blanc, L. Les hydro-écorégions de France métropolitaine. Approche régionale de la typologie des eaux courantes et éléments pour la définition des peuplements de référence d'invertébrés. Ministère de l'Ecologie et du Développement Durable, Cemagref BEA/LHQ., pp. 190; 2002.

Whyte, J.J.; Jung, R.E.; Schmitt, C.J.; Tillitt, D.E. Ethoxyresorufin-O-deethylase (EROD) activity in fish as a biomarker of chemical exposure. Crit. Rev. Toxicol. 30: 347-570; 2000.

Wootton, R.J. The biology of the sticklebacks. Academic Press, London New York San Francisco, pp. 376; 1976. 
Table 1 : List of pesticides measured in water and/or sediment sampled at every sampling period.

\begin{tabular}{|c|c|c|}
\hline & Water & Sediment \\
\hline Aclonifen & & $\mathrm{X}$ \\
\hline Alachlor & $\mathrm{X}$ & $\mathrm{X}$ \\
\hline Aldrin & $\mathrm{X}$ & $X$ \\
\hline Atrazine & $\mathrm{X}$ & $X$ \\
\hline Deisopropyl-atrazine & $\mathrm{X}$ & \\
\hline Desethyl-atrazine & $\mathrm{X}$ & \\
\hline Chlorpyriphos ethyl & $\mathrm{X}$ & $X$ \\
\hline Desmetryn & & $X$ \\
\hline Dieldrin & $\mathrm{X}$ & $\mathrm{X}$ \\
\hline$\alpha$-endosulfan & $\mathrm{X}$ & $X$ \\
\hline$\beta$-endosulfan & $X$ & $\mathrm{X}$ \\
\hline Ethofumesate & $\mathrm{X}$ & $X$ \\
\hline Flusilazole & $\mathrm{X}$ & \\
\hline$\alpha \mathrm{HCH}$ & $\mathrm{X}$ & $\mathrm{X}$ \\
\hline$\beta \mathrm{HCH}$ & $\mathrm{X}$ & $X$ \\
\hline$\gamma \mathrm{HCH}$ & $\mathrm{X}$ & $\mathrm{X}$ \\
\hline Heptachlor & $\mathrm{X}$ & $X$ \\
\hline Heptachlorepoxide & $X$ & $X$ \\
\hline
\end{tabular}


Hexachlorobenzene

Metolacholor

Metribuzine

Propazine

Simazine

Terbuthylazine

Desethyl-terbuthylazine
Prometryn

$\mathrm{X}$

X

X $\quad$ X

X

X $\quad$ X

X $\quad$ X

X $\quad X$

Terbutryn

X

Triallate

Trifluraline

X

X 
Table 2 : Physico-chemical parameters, metal and pesticide concentrations measured in water samples collected at every sampling periods. LOD : Limit Of Detection.

\begin{tabular}{|c|c|c|c|c|c|c|}
\hline & April & May & June & August & September & October \\
\hline Temperature $\left({ }^{\circ} \mathrm{C}\right)$ & 11.5 & 13.1 & 11.5 & 11.7 & 12.0 & 11.7 \\
\hline $\mathrm{pH}$ & 7.19 & 7.61 & 7.13 & 7.10 & 7.58 & 7.42 \\
\hline Dissolved $\mathrm{O}_{2}(\mathrm{mg} / \mathrm{L})$ & 11.8 & 10.8 & 8.7 & 10.5 & 11.7 & 11.2 \\
\hline Conductivity $(\mu \mathrm{S} / \mathrm{cm})$ & 519 & 496 & 521 & 526 & 489 & 487 \\
\hline Hardness $\left(\mathrm{mg} \mathrm{CaCO}_{3} / \mathrm{L}\right)$ & 280 & 240 & 160 & 240 & 180 & 200 \\
\hline $\mathrm{Cd}(\mu \mathrm{g} / \mathrm{L})$ & $<\mathrm{LOD}$ & $<\mathrm{LOD}$ & $<\mathrm{LOD}$ & $<\mathrm{LOD}$ & $<\mathrm{LOD}$ & $<\mathrm{LOD}$ \\
\hline $\mathrm{Cr}(\mu \mathrm{g} / \mathrm{L})$ & 0.77 & 0.76 & 0.66 & 0.72 & 0.83 & 0.82 \\
\hline $\mathrm{Cu}(\mu \mathrm{g} / \mathrm{L})$ & 1.3 & 0.76 & $<\mathrm{LOD}$ & 0.63 & 1.0 & 1.0 \\
\hline
\end{tabular}




\begin{tabular}{|c|c|c|c|c|c|c|}
\hline $\mathrm{Ni}(\mu \mathrm{g} / \mathrm{L})$ & $<\mathrm{LOD}$ & $<\mathrm{LOD}$ & 2.1 & 1.1 & 4.7 & 16.2 \\
\hline $\mathrm{Pb}(\mu \mathrm{g} / \mathrm{L})$ & 0.3 & 0.17 & 0.19 & 0.43 & 0.54 & 0.65 \\
\hline $\operatorname{Sn}(\mu \mathrm{g} / \mathrm{L})$ & $<\mathrm{LOD}$ & $<\mathrm{LOD}$ & $<\mathrm{LOD}$ & $<\mathrm{LOD}$ & $<\mathrm{LOD}$ & $<\mathrm{LOD}$ \\
\hline $\mathrm{Zn}(\mu \mathrm{g} / \mathrm{L})$ & 10.5 & 7.6 & 9.5 & 4.9 & 5.6 & 4.1 \\
\hline Pesticides $(\mu \mathrm{g} / \mathrm{L})$ & $<\mathrm{LOD}$ & $<\mathrm{LOD}$ & $<\mathrm{LOD}$ & $<\mathrm{LOD}$ & $<\mathrm{LOD}$ & $<\mathrm{LOD}$ \\
\hline
\end{tabular}


Table 3 : PAH, PCB and pesticide concentrations measured in sediment extracts for every sampling periods. Data are expressed as $\mu \mathrm{g} / \mathrm{kg}$.

\begin{tabular}{|c|c|c|c|c|c|c|}
\hline & April & May & June & August & September & October \\
\hline Fluoranthène & 200 & 180 & 180 & 150 & 210 & 150 \\
\hline Benzo (b) fluoranthène & 110 & 100 & 100 & 95 & 110 & 120 \\
\hline Benzo $(\mathrm{k})$ fluoranthène & 40 & 30 & 50 & 35 & 70 & 55 \\
\hline Benzo (a) pyrène & 90 & 60 & 70 & 65 & 90 & 90 \\
\hline Benzo $(\mathrm{g}, \mathrm{h}, \mathrm{i})$ pérylène & 65 & 40 & 50 & 45 & 60 & $<\mathrm{LOD}$ \\
\hline Indéno $(1,2,3, \mathrm{c}, \mathrm{d})$ pyrène & 55 & 40 & 45 & 40 & 55 & $<\mathrm{LOD}$ \\
\hline Phénanthrène & 85 & 95 & 110 & 85 & 120 & 70 \\
\hline Anthracène & 15 & 10 & 15 & 15 & 20 & 15 \\
\hline Pyrène & 160 & 150 & 150 & 130 & 190 & 120 \\
\hline
\end{tabular}




\begin{tabular}{|c|c|c|c|c|c|c|}
\hline Benzo (a) anthracène & 85 & 65 & 70 & 65 & 95 & 60 \\
\hline Chrysène & 100 & 90 & 90 & 75 & 110 & 75 \\
\hline Dibenzo $(\mathrm{a}, \mathrm{h})$ anthracène & $<\mathrm{LOD}$ & $<\mathrm{LOD}$ & 15 & 10 & 10 & $<\mathrm{LOD}$ \\
\hline PCBs & $<\mathrm{LOD}$ & $<\mathrm{LOD}$ & $<\mathrm{LOD}$ & $<\mathrm{LOD}$ & $<\mathrm{LOD}$ & $<\mathrm{LOD}$ \\
\hline Pesticides & $<\mathrm{LOD}$ & $<\mathrm{LOD}$ & $<\mathrm{LOD}$ & $<\mathrm{LOD}$ & $<\mathrm{LOD}$ & $<\mathrm{LOD}$ \\
\hline
\end{tabular}


Table 4 : Somatic indexes and condition factor for three-spined sticklebacks (G. aculeatus L.) collected at all sampling periods. Data are presented as mean \pm SD. Values annotated with different letters are significantly different (ANOVA followed by Sidak post-hoc test, $\alpha=5 \%$ ).

\begin{tabular}{|c|c|c|c|c|c|c|c|}
\hline & Sex & April & May & June & August & September & October \\
\hline & $\hat{0}$ & $2.8 \pm 0.9^{\mathrm{a}}$ & $2.6 \pm 0.8^{\mathrm{a}}$ & $2.4 \pm 0.5^{\mathrm{a}}$ & $2.5 \pm 0.8^{\mathrm{a}}$ & $2.3 \pm 0.5^{\mathrm{a}}$ & $2.3 \pm 0.4^{\mathrm{a}}$ \\
\hline \multicolumn{8}{|c|}{ HSI } \\
\hline & $q$ & $3.6 \pm 0.9^{\mathrm{a}}$ & $3.9 \pm 1.0^{\mathrm{a}}$ & $3.5 \pm 0.6^{\mathrm{a}}$ & $2.7 \pm 0 \cdot 7^{\text {a.b }}$ & $2.5 \pm 0.6^{b}$ & $2.2 \pm 0.4^{\mathrm{b}}$ \\
\hline & $\hat{0}$ & $0.5 \pm 0.3^{\mathrm{a}}$ & $0.7 \pm 0.4^{\mathrm{a}}$ & $0.7 \pm 0.6^{\mathrm{a}}$ & $0.9 \pm 0.5^{\mathrm{a}}$ & $0.7 \pm 0.4^{\mathrm{a}}$ & $0.9 \pm 0.5^{\mathrm{a}}$ \\
\hline \multicolumn{8}{|c|}{ GSI } \\
\hline & q & $3.6 \pm 1.5^{\mathrm{a}}$ & $3.1 \pm 1.1^{\mathrm{a}}$ & $2.5 \pm 1.4^{\mathrm{a}}$ & $1.3 \pm 0.7^{\mathrm{b}}$ & $1.6 \pm 0.6^{a . b}$ & $1.4 \pm 0.8^{\mathrm{a} . \mathrm{b}}$ \\
\hline & $\hat{0}$ & $2.3 \pm 0.9^{\mathrm{a}}$ & $1.8 \pm 0.8^{\mathrm{a}}$ & $2.0 \pm 0.8^{\mathrm{a}}$ & $0.5 \pm 0.3^{\mathrm{b}}$ & $0.4 \pm 0.1^{\mathrm{b}}$ & $0.5 \pm 0.2^{\mathrm{b}}$ \\
\hline \multicolumn{8}{|c|}{ NSI } \\
\hline & q & $0.6 \pm 0.3^{\mathrm{a}}$ & $0.5 \pm 0.2^{\mathrm{a}}$ & $0.6 \pm 0.3^{\mathrm{a}}$ & $0.2 \pm 0.1^{\mathrm{a}}$ & $0.5 \pm 0.2^{\mathrm{a}}$ & $0.5 \pm 0.3^{\mathrm{a}}$ \\
\hline $\mathrm{CF}$ & $\widehat{\partial}$ and $\rho$ & $0.9 \pm 0.1^{\mathrm{a}}$ & $0.9 \pm 0.1^{\mathrm{a}}$ & $1.0 \pm 0.2^{\mathrm{a}}$ & $0.8 \pm 0.1^{\mathrm{a}}$ & $0.8 \pm 0.1^{\mathrm{a}}$ & $0.8 \pm 0.1^{\mathrm{a}}$ \\
\hline
\end{tabular}


Table 5 : Biomarker values measured for three-spined sticklebacks (G. aculeatus L.) collected at all sampling periods. Data are presented as mean \pm SD. Values annotated with different letters are significantly different (ANOVA followed by Sidak post-hoc test, $\alpha=5 \%$ ).

\begin{tabular}{|c|c|c|c|c|c|c|c|}
\hline & \multirow[b]{2}{*}{ Sex } & \multicolumn{6}{|c|}{ Sampling period } \\
\hline & & April & May & June & August & September & October \\
\hline \multirow{3}{*}{ EROD $^{\mathrm{a}}$} & 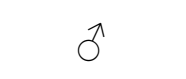 & $6.3 \pm 1.8^{\mathrm{a}}$ & $4.9 \pm 1.4^{\mathrm{a}}$ & $5.8 \pm 2.1^{\mathrm{a}}$ & $4.1 \pm 1.3^{\mathrm{a}}$ & $5.7 \pm 1.6^{\mathrm{a}}$ & $6.5 \pm 2.9^{\mathrm{a}}$ \\
\hline & & & & & & & \\
\hline & q & $3.1 \pm 1.0^{\mathrm{a} . \mathrm{b}}$ & $2.7 \pm 1.5^{\mathrm{a}}$ & $2.9 \pm 1.7^{\mathrm{a}}$ & $5.3 \pm 1.6^{\mathrm{b}}$ & $6.9 \pm 1.2^{b}$ & $5.8 \pm 2.0^{\mathrm{b}}$ \\
\hline $\mathrm{GST}^{\mathrm{b}}$ & $\delta$ and $q$ & $1,258 \pm 471^{\mathrm{a}}$ & $993 \pm 183^{b}$ & $1,175 \pm 355^{\mathrm{a}}$ & $1,059 \pm 342^{a . b}$ & $1,06 \pm 496^{\mathrm{a}}$ & $1,247 \pm 362^{a}$ \\
\hline \multirow{2}{*}{$\mathrm{GPx}^{\mathrm{b}}$} & $\widehat{0}$ & $63 \pm 21^{\mathrm{a}}$ & $79 \pm 27^{\mathrm{a} \cdot \mathrm{b}}$ & $59 \pm 16^{\mathrm{a}}$ & $88 \pm 36^{\mathrm{b}}$ & $104 \pm 35^{b}$ & $97 \pm 23^{b}$ \\
\hline & q & $126 \pm 45^{\mathrm{a} . \mathrm{b}}$ & $142 \pm 41^{\mathrm{a}}$ & $107 \pm 33^{b}$ & $151 \pm 49^{\mathrm{a}}$ & $138 \pm 41^{\mathrm{a} . \mathrm{b}}$ & $124 \pm 26^{a . b}$ \\
\hline $\mathrm{GSH}^{\mathrm{c}}$ & $\widehat{\jmath}$ and $q$ & $37.1 \pm 10.1^{\mathrm{a}}$ & $48.8 \pm 14.5^{\mathrm{b}}$ & $50.2 \pm 23.9^{a . b}$ & $19.7 \pm 9.7^{\mathrm{c}}$ & $31.6 \pm 14.8^{\mathrm{a} . \mathrm{c}}$ & $24.3 \pm 10.9^{c}$ \\
\hline TBARS $^{\mathrm{d}}$ & $\widehat{\gamma}$ and $q$ & $52 \pm 19^{\mathrm{a}}$ & $60 \pm 21^{\mathrm{a}}$ & $43 \pm 16^{\mathrm{a}}$ & $48 \pm 18^{\mathrm{a}}$ & $61 \pm 28^{\mathrm{a}}$ & $44 \pm 20^{\mathrm{a}}$ \\
\hline
\end{tabular}




\begin{tabular}{|c|c|c|c|c|c|c|c|}
\hline $\mathrm{AChE}^{\mathrm{e}}$ & $\delta$ and $q$ & $84 \pm 22^{a}$ & $91 \pm 30^{\mathrm{a}}$ & $75 \pm 24^{\mathrm{a}}$ & $89 \pm 18^{\mathrm{a}}$ & $101 \pm 26^{\mathrm{a}}$ & $97 \pm 23^{\circ}$ \\
\hline & 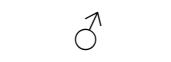 & $<\mathrm{LOD}$ & $<\mathrm{LOD}$ & $<\mathrm{LOD}$ & $<\mathrm{LOD}$ & $<\mathrm{LOD}$ & $<\mathrm{LOD}$ \\
\hline \multicolumn{8}{|l|}{$\mathrm{VTG}^{\mathrm{f}}$} \\
\hline & q & $22,648 \pm 19,461^{\mathrm{a}}$ & $29,064 \pm 20,037^{\mathrm{a}}$ & $5,532 \pm 8,968^{a}$ & $<\mathrm{LOD}$ & $<\mathrm{LOD}$ & $<\mathrm{LOD}$ \\
\hline & $\widehat{\jmath}$ & $7,628 \pm 5,103^{\mathrm{a}}$ & $10,571 \pm 6,075^{\mathrm{a}}$ & $6,358 \pm 5,994^{\mathrm{a}}$ & $<\mathrm{LOD}$ & $<\mathrm{LOD}$ & $<\mathrm{LOD}$ \\
\hline \multicolumn{8}{|l|}{$\mathrm{SPG}^{\mathrm{g}}$} \\
\hline & q & $<\mathrm{LOD}$ & $<\mathrm{LOD}$ & $<\mathrm{LOD}$ & $<\mathrm{LOD}$ & $<\mathrm{LOD}$ & $<\mathrm{LOD}$ \\
\hline
\end{tabular}

$\mathrm{a}$ : EROD is expressed as $\mathrm{pmol} / \mathrm{min} / \mathrm{mg}$ of proteins

b : GST and GPx are expressed as U/g of proteins

$\mathrm{c}: \mathrm{GSH}$ is expressed as $\mu \mathrm{mol} / \mathrm{g}$ of proteins

$\mathrm{d}$ : TBARS is expressed as $\mathrm{nmol} / \mathrm{g}$ of proteins

e : AChE is expressed as U/mg of proteins

$\mathrm{f}$ : VTG is expressed as $\mu \mathrm{g} / \mathrm{mL}$ of total blood

$\mathrm{g}: \mathrm{SPG}$ is expressed as $\mathrm{U} / \mathrm{g}$ of fish 
Table 6 : Biomarker basal levels established for both male and female three-spined stickleback ( $\underline{\mathrm{G}}$. aculeatus L.) in reproductive and non reproductive status, sampled in the "Tables calcaires" hydroecoregion. Data are presented as mean \pm SD. The unit are presented in Table 5.

\begin{tabular}{|c|c|c|c|}
\hline & Sex & Reproductive & Non reproductive \\
\hline \multirow{3}{*}{ EROD } & $\pi$ & $5.3 \pm 1.7$ & \multirow{3}{*}{$6.2 \pm 2.1$} \\
\hline & & \multirow[b]{2}{*}{$3.0 \pm 1.5$} & \\
\hline & q & & \\
\hline GST & $\delta$ and $q$ & \multicolumn{2}{|c|}{$1,236 \pm 396$} \\
\hline \multirow{3}{*}{ GPx } & 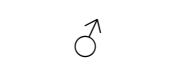 & $68 \pm 22$ & $95 \pm 35$ \\
\hline & & & \\
\hline & q & \multicolumn{2}{|c|}{$135 \pm 41$} \\
\hline GSH & $\delta$ and $q$ & \multicolumn{2}{|c|}{$32.7 \pm 15.9$} \\
\hline TBARS & $\widehat{\delta}$ and $q$ & \multicolumn{2}{|c|}{$49.5 \pm 22$} \\
\hline $\mathrm{AChE}$ & $\delta$ and $q$ & \multicolumn{2}{|c|}{$93 \pm 26$} \\
\hline \multirow{2}{*}{ VTG } & 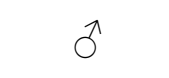 & \multicolumn{2}{|c|}{$<\mathrm{LOD}$} \\
\hline & q & $18,109 \pm 20,308$ & $<\mathrm{LOD}$ \\
\hline \multirow{3}{*}{ SPG } & $\sigma^{\pi}$ & $8,216 \pm 5,559$ & $<\mathrm{LOD}$ \\
\hline & & & \\
\hline & o & \multicolumn{2}{|c|}{$<\mathrm{LOD}$} \\
\hline
\end{tabular}

